\title{
Body Mass Index is not an Independent Predictor for Missed Injury on Chest X-ray compared with Chest Computed Tomography
}

\author{
Poornima Vanguri, Rahul Anand, Michel Aboutanos, Rao Ivatury, Paula Ferrada
}

\begin{abstract}
Objective: Obesity is a risk factor for morbidity and mortality in the polytraumatized patient. The aim of this study is to determine if obesity is an independent risk factor for missed injury in chest X-ray after trauma.
\end{abstract}

Materials and methods: Institutional Review Board approval was obtained. We performed a retrospective review of patients who presented to a level one trauma center as the higher acuity alerts from September 2010 to July 2011. We compared the chest X-ray with the chest computed tomography (CT) findings. Variables, such as age, BMI, mechanism, admission to the ICU and mortality during the same hospital stay, were evaluated.

Results: A total of 224 patients met these criteria. The majority of patients were of male gender (79\%). Average age was 40 years. Average ISS was 19.7. Mean BMI was 26.7 with 103 patients with $\mathrm{BMI}<25$ and with 123 patients with $\mathrm{BMI}>25$. Mechanisms included blunt $(n=167)$, penetrating $(n=50)$ and burns $(n=7)$. A total of 123 patients $(54.4 \%)$ had undiagnosed thoracic injuries by chest X-ray that were found on chest CT scan. Eighty-five percent of patients with missed injuries on chest $X$-ray required ICU admission as a result of the thoracic trauma. Missed injuries were as follows; rib fractures with or without flail chest $(n=62)$, pneumothorax $(n=40)$, hemothorax ( $n=$ $42)$, sternal fracture $(n=15)$, pulmonary lacerations/contusion $(n=60)$, great vessel injuries $(n=6)$, and blunt ventricular rupture $(n=1)$. Strikingly, there was no significant difference in missed injury, ICU admission or mortality when obese patients were compared to nonobese patients.

Conclusion: Chest X-ray undermines the degree of injury in blunt trauma patients. BMI is not an independent predictor of missed injury, ICU admission or mortality during the same hospital stay.

Keywords: Obesity, Chest X-ray, Chest CT, Body mass index.

How to cite this article: Vanguri $P$, Anand $R$, Aboutanos $M$, Ivatury $R$, Ferrada P. Body Mass Index is not an Independent Predictor for Missed Injury on Chest X-ray compared with Chest Computed Tomography. Panam J Trauma Critical Care Emerg Surg 2013;2(1):45-48.

Source of support: Nil

Conflict of interest: None declared

\section{RESUMEN}

Objetivo: La obesidad es un factor de riesgo que aumenta morbilidad y mortalidad en los pacientes politraumatizados. El objetivo de este estudio es determinar si la obesidad es un factor de riesgo independiente para lesiónes indavertidas en la radiografía de tórax después de un trauma.
Métodos: Se realizo una revisión retrospectiva de los pacientes que acudieron a un centro de trauma de nivel uno como las alertas de mayor agudeza entre septiembre de 2010 julio de 2011. Se comparó la radiografía de tórax con el TC de tórax. Variables como la edad, el IMC, el mecanismo, admisión a la Unidada de Cuidaos Intensivos (UCl) y la mortalidad durante el mismo ingreso hospitalario fueron evaluados.

Resultados: 224 pacientes cumplieron con estos criterios. La mayoría de los pacientes eran de sexo masculino (79\%). El promedio de edad fue de 40 años. Promedio ISS fue de 19,7. El IMC promedio fue de 26,7 por 103 pacientes con IMC < 25 y con 123 pacientes con IMC> 25. Mecanismos incluidos fueron trauma cerrado $(n=167)$, penetrante $(n=50)$ y quemaduras $(n=7) .123$ pacientes $(54,4 \%)$ tenían heridas torácicas no diagnosticadas por radiografía de tórax que se encontraron en el TC de torax. El ochenta y cinco por ciento de los pacientes con lesiones inadvertidas en la radiografía de tórax necesitaron admisión en la $\mathrm{UCl}$ debido al trauma torácico. Lesiones inadvertidas furon las siguientes: fracturas de costillas, con o sin tórax inestable $(n=62)$, neumotórax $(n=40)$, hemotórax $(n=42)$, fractura esternal $(n=15)$, laceraciones pulmonares /contusiónes $(n=60)$, lesiones de grandes vasos $(n=6)$, y ruptura ventricular secundaria a trauma cardiaco cerrado $(n=1)$. Sorprendentemente, no hubo diferencia significativa en la lesión inadvertida, ingreso en la $\mathrm{UCl}$ o la mortalidad cuando los pacientes obesos se compararon con los pacientes no obesos.

Conclusiones: Radiografía de tórax minimiza el grado de la lesión en pacientes con traumatismo contuso. IMC no es un predictor independiente de lesión inadvertida, la admisión en la $\mathrm{UCl}$ o mortalidad durante la estancia hospitalaria mismo.

Palabras claves: La obesidad, La radiografía de tórax, TC de tórax, El índice de masa corporal.

\section{INTRODUCTION}

Obesity is an increasing epidemic worldwide. ${ }^{1}$ According to the Disease Control and Prevention and the National Health and Nutrition Examination Survey, as of 2010, more than one third of all American adults are obese. ${ }^{2}$ In spite of cultural and dietary differences, obesity has also been a problem in Europe, affecting about $30 \%$ of the population. As the problem of obesity increases, traumatic injuries in these obese patients are seen more often. ${ }^{3}$

In some studies, obesity has been shown to be a risk factor for multisystem organ failure (MSOF) and death after blunt trauma. ${ }^{4-7}$ Conversely, in some cases, obesity can be 
protective in chest trauma. ${ }^{8}$ Chest X-ray has been shown to have a low sensitivity and specificity for pneumothorax, pleural effusions and pneumonia, especially when compared with other diagnostic aids. ${ }^{9}$ In trauma specifically, computed tomographic (CT) scan has been shown to be superior to chest X-ray in identifying contusions, pneumothorax and hemothorax. ${ }^{10}$

The objective of this study was to evaluate whether obesity is an independent risk factor for a missed traumatic injury in the initial chest $X$-ray that was subsequently found on chest $\mathrm{CT}$. For the purposes of this study, body mass index (BMI) was evaluated in categories of underweight with BMI $<18.5$, healthy with BMI 18.5 to 25 , overweight as BMI $>$ 25 , obesity class 1 as BMI 30 to 35 , obesity class 2 as BMI 35 to 40 and morbid obesity as BMI $>40 .{ }^{11}$

\section{MATERIALS AND METHODS}

Institutional Review Board approval was obtained. A retrospective review was performed of all patients who presented to a level one trauma center as a 'delta' alert (highest acuity) greater than 16 years of age who received chest X-ray and subsequent chest CT scan from September 2010 to July 2011. A delta trauma alert was defined as any patient who had a reported systolic blood pressure $<90$ en route, respiratory compromise, received blood products, had a Glasgow Coma Score $<8$, suffered gunshot wounds to the abdomen, neck or chest, or stab wound to the neck, chest, abdomen or head with hemodynamic instability, had known flail chest, two or more long-bone fractures, paralysis or major burns.

Patients in this center's trauma registry who met these criteria underwent retrospective chart review. Chest X-ray results were compared with chest $\mathrm{CT}$ findings. In addition, age, BMI, mechanism of trauma, ICU admission and mortality were evaluated in each of these patients by chart review. Height and weight values were noted to be 'actual, estimated or stated' and injuries were ascertained from radiology reads of the images that were finalized by attending radiologists. BMI was calculated as weight in kilograms divided by height in meters squared.

Variables were analyzed with Statistical Analysis Software (SAS). T-test and Fisher's exact test were used to analyze for correlation between variables and outcomes.

\section{RESULTS}

In this review, 224 patients met criteria. The average age of the patients was 40.9 years. Most patients were male (79\%) and the average Injury Severity Score (ISS) was 19.7. The mean BMI was $26.7 \mathrm{~kg} / \mathrm{m}^{2}$. In terms of BMI, $103(45.6 \%)$ patients had a reported $\mathrm{BMI}<25$ and $123(54.9 \%)$ patients had a BMI $>25$ and therefore were at least overweight by the definitions above.

Mechanism of injury was identified through the registry and confirmed by chart review where $167(74.6 \%)$ patients suffered blunt trauma, 50 (22.3\%) had penetrating injuries and $7(3.1 \%)$ suffered burn injuries. After review of the chest X-rays and CT scans, 123 (54.9\%) patients had undiagnosed thoracic injuries on chest X-ray that were identified by chest CT. Of these patients, $85 \%$ required ICU admission. Missed injuries included rib fractures with or without flail chest, pneumothorax, hemothorax, sternal fractures, pulmonary lacerations/contusions, great vessel injuries and blunt ventricular rupture (Table 1).

\begin{tabular}{|c|c|}
\hline \multicolumn{2}{|c|}{ injury seen on CT } \\
\hline Type of missed injury seen on CT & Number of patients \\
\hline Rib fractures \pm flail segment & 62 \\
\hline Pneumothorax & 40 \\
\hline Hemothorax & 42 \\
\hline Sternal fractures & 15 \\
\hline Pulmonary laceration/contusion & 60 \\
\hline Great vessel injury & 6 \\
\hline Blunt ventricular rupture & 1 \\
\hline
\end{tabular}

BMI, as well as the categories of BMI, ISS and age were compared with the categorical variables of ICU admission, mortality and type of injury (blunt, penetrating, or burn). In addition, they were compared with the likelihood of missed injury from chest X-ray to CT scan and those with missed injury requiring ICU admission. Patients with missed injury were more significantly likely to have ICU admission ( $\mathrm{p}=$ 0.028). In addition, those with missed injuries had a higher ISS $(p<0.0001)$. There was no significant correlation of those in the higher BMI categories having more missed injuries compared to those in the lower BMI categories. There was also no significant correlation between BMI and ICU admission or mortality demonstrated by t-test.

\section{DISCUSSION}

As obesity has increased in prevalence, it has become a significant factor in the care of trauma patients. ${ }^{12}$ Several studies have now been undertaken to establish patterns of injury and correlation of outcomes in obese patients. ${ }^{13}$ As chest X-ray can miss some important injuries in trauma patients; $;, 10$ we aimed to identify if patients with increased BMI were at greater risk for missed injury when comparing the use of chest X-ray vs CT scan. 
Studies have previously shown an increase in mortality in severely overweight $(\mathrm{BMI}>31)$ patients after trauma. ${ }^{14}$ In fact, a significant correlation with $\mathrm{BMI}>30$ and thoracic injuries, such as rib fractures and pulmonary contusions, has been demonstrated but with a lower incidence of flail chest. ${ }^{15}$

Subsequent studies have demonstrated varied results. In a large retrospective review, obese patients were found to have significantly more chest injury, and increased mortality $(p=0.03) .{ }^{16}$ In contrast, another study examined trauma admissions retrospectively and examined 24-hour glucose and BMI. In this study, age, ISS and hyperglycemia were found to be independent risk factors for mortality but did not find morbid obesity with a BMI $>40$ to be an independent risk factor of mortality in patient surviving past the first 72 hours. $^{17}$

Obesity has been shown to have a direct association with developing MSOF as well as increased mortality in the ICU. ${ }^{4}$ It is suggested in the literature that these changes in outcome could be a result of an anomalous inflammatory response to injury in obese patients. ${ }^{6}$ However, studies have not been able to define a clear correlation with leukocytic inflammatory response and obesity. ${ }^{7}$

The variety of data and conclusions that have been drawn about obesity and injury demonstrates that there is a complexity to this question beyond looking at a population and determining their outcomes. We question whether obesity alone is an independent factor for missed injury after chest trauma.

The result of this present manuscript demonstrates that obesity is not an independent factor for missed injuries in the chest. It shows, however, that missed chest injuries are significant because many patients with these types of injuries required ICU admission.

\section{LIMITATIONS}

This was a small cohort of people relative to some of the large retrospective reviews previously mentioned. Reported BMI could be a limiting factor in this study as it was sometimes reported as estimated.

\section{CONCLUSION}

Chest X-ray undermines the degree of injury in trauma victims of different mechanisms. CT scan can identify several injuries that are not seen on chest X-ray. In this study, those with missed injuries had higher ICU admissions. BMI was not an independent predictor of undiagnosed thoracic injury by chest X-ray, ICU admission or mortality. This demonstrates that obese and nonobese trauma patients should undergo comprehensive workups particularly in the case of undergoing a chest CT due to the risk of missing injuries that can affect outcome.

\section{REFERENCES}

1. James PT. Obesity: The worldwide epidemic. Clin Dermatol 2004;22(4):276-80.

2. Ogden CL, Carroll MD, Kit BK, Flegal KM. Prevalence of obesity in the United States 2009-2010. NCHS Data Brief 2012;(82):1-8.

3. Berghofer A, Pischon T, Reinhold T, Apovian CM, Sharma AM, Willich SN. Obesity prevalence from a European perspective: A systematic review. BMC Public Health 2008;8:200.

4. Bercault N, Boulain T, Kuteifan K, Wolf M, Runge I, Fleury JC. Obesity-related excess mortality rate in an adult intensive care unit: A risk-adjusted matched cohort study. Crit Care Med 2004;32(4):998-1003.

5. Byrnes MC, McDaniel MD, Moore MB, Helmer SD, Smith RS. The effect of obesity on outcomes among injured patients. J Trauma 2005;58(2):232-37.

6. Ciesla DJ, Moore EE, Johnson JL, Burch JM, Cothren CC, Sauaia A. Obesity increases risk of organ failure after severe trauma. J Am Coll Surg 2006;203(4):539-45.

7. Winfield RD, Delano MJ, Dixon DJ, et al. Differences in outcome between obese and nonobese patients following severe blunt trauma are not consistent with an early inflammatory genomic response. Crit Care Med 2010;38(1):51-58.

8. Anand RJ, Whelan JF, Ferrada P, Duane TM. Thin chest wall is an independent risk factor for the development of pneumothorax after chest tube removal 2012;78(4):478-80.

9. Gardelli G, Feletti F, Nanni A, Mughetti M, Piraccini A, Zompatori M. Chest ultrasonography in the ICU. Respir Care 2012;57(5):773-81.

10. Trupka A, Waydhas C, Hallfeldt KK, Nast-Kolb D, Pfeifer KJ, Schweiberer L. Value of thoracic computed tomography in the first assessment of severely injured patients with blunt chest trauma: Results of a prospective study. J Trauma 1997;43(3):40511; discussion 411-12.

11. Obesity: Preventing and managing the global epidemic. Report of a WHO consultation. World Health Organ Tech Rep Ser 2000;894:i-xii, 1-253.

12. Ziglar MK. Obesity and the trauma patient: Challenges and guidelines for care. J Trauma Nurs 2006;13(1):22-27.

13. Brown CV, Velmahos GC. The consequences of obesity on trauma, emergency surgery, and surgical critical care. World J Emerg Surg 2006;1:27.

14. Choban PS, Weireter LJ Jr, Maynes C. Obesity and increased mortality in blunt trauma. J Trauma 1991;31(9):1253-57.

15. Boulanger BR, Milzman D, Mitchell K, Rodriguez A. Body habitus as a predictor of injury pattern after blunt trauma. $\mathrm{J}$ Trauma 1992;33(2):228-32.

16. Brown CV, Neville AL, Rhee P, Salim A, Velmahos GC, Demetriades D. The impact of obesity on the outcomes of 1,153 critically injured blunt trauma patients. J Trauma 2005;59(5):1048-51; discussion 1051.

17. Diaz JJ Jr, Norris PR, Collier BR, et al. Morbid obesity is not a risk factor for mortality in critically ill trauma patients. J Trauma 2009;66(1):226-31.

\section{ABOUT THE AUTHORS}

\section{Poornima Vanguri (Corresponding Author)}

Resident, Department of Surgery, Virginia Commonwealth University Richmond, Virginia, United States, e-mail: pvanguri@mcvh-vcu.edu 


\section{Rahul Anand}

Assistant Professor, Department of Surgery, Virginia Commonwealth University, Richmond, Virginia, United States

\section{Michel Aboutanos}

Professor, Department of Surgery, Virginia Commonwealth University Richmond, Virginia, United States

\section{Rao Ivatury}

Professor, Department of Surgery, Virginia Commonwealth University Richmond, Virginia, United States

\section{Paula Ferrada}

Assistant Professor, Department of Surgery, Virginia Commonwealth University, Richmond, Virginia, United States 